\title{
'Dentists' and the establishment of the Anglo-American dental profession in the eighteenth century: part 1. The need for a name and an identity
}

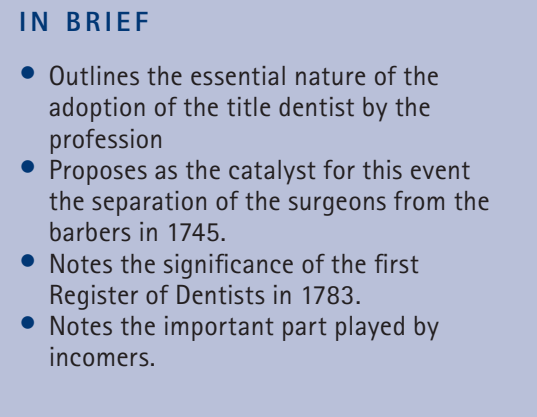

M. Bishop ${ }^{1}$

This series of papers will examine how the Anglo-American dental profession was established in the eighteenth century, examining its need for a name and identity, public recognition and official status. This paper outlines the evolution of the names of the profession, from tooth-drawer to dentist, and notes the importance of the name to the profession.

\section{INTRODUCTION}

In 2005, Stephen Hancocks, in an editorial in which he discussed appropriate names to apply to members of the dental team said: "They may be just words but they are essential words for, and words essential to, our identity. Until we can agree that identity among ourselves we cannot expect others such as patients, public, media and politicians to either understand our relationship to one another or indeed to respect our collective voice when we choose to, or need to, use it."

Just over 250 years ago, the need for a satisfactory title for those practitioners who had begun to specialise in dentistry suddenly became urgent. When the surgeons split from the Company of Barber Surgeons in 1745, ${ }^{2}$ these practitioners had no collective title. Operators for the teeth were distinct from the various kinds of tooth-drawer, but neither title was suitable for a new speciality branch of surgery, whose members were not entitled to be part of the new Surgeons Company, and who did not wish to be associated any more with the barbers.

Hancocks' statement can be broken down into three components - selfawareness (agreed identity among

'Unit for the History of Dentistry at King's College London Dental Institute

Correspondence to: Malcolm Bishop

Email: malcolmbishop57@btinternet.com

\section{Refereed Paper}

Accepted 18 June 2014

DOI: 10.1038/sj.bdj.2014.951

${ }^{\circ}$ British Dental Journal 2014; 217: 537-540 ourselves), public awareness (others such as patients, public, media) and political identity (politicians [who] understand our relationship to one another [and] respect our collective voice).

This series of papers describes how between 1745 and the close of the eighteenth century in both England and North America, dental practitioners adopted the name by which they are now known, from the French 'dentiste', which quickly satisfied the three Hancocks criteria for a professional title. In acquiring the title, the profession was created.

\section{DENTISTS IN THE MEDICAL REGISTER OF 1783}

In 1783, a landmark document in the history of British dentistry was published. Modern in concept and thorough in execution, the third edition of The Medical Register for the year included for the first time a listing of 18 dentists, 15 established in London (Fig. 1), 2 in Oxford and 1 in Liverpool.

Over the previous 30 years several individual practitioners had been known as dentists, but the Medical Register established the term as the group title and fixed their place within the medical hierarchy, after physicians, surgeons, apothecaries, aurists and oculists.

The London dentists were; Thomas Berdmore (dentist to His Majesty), Brotherson, Franklin, James Hemet (dentist to the Queen and her Royal Highness the Princess Amelia), Jullion, Ladomiey, Michaelson, Normansell, William Rae (dentist to the Foundling Hospital), Bartholomew Ruspini, J. Spence, T. Spence (dentist to His Majesty), another

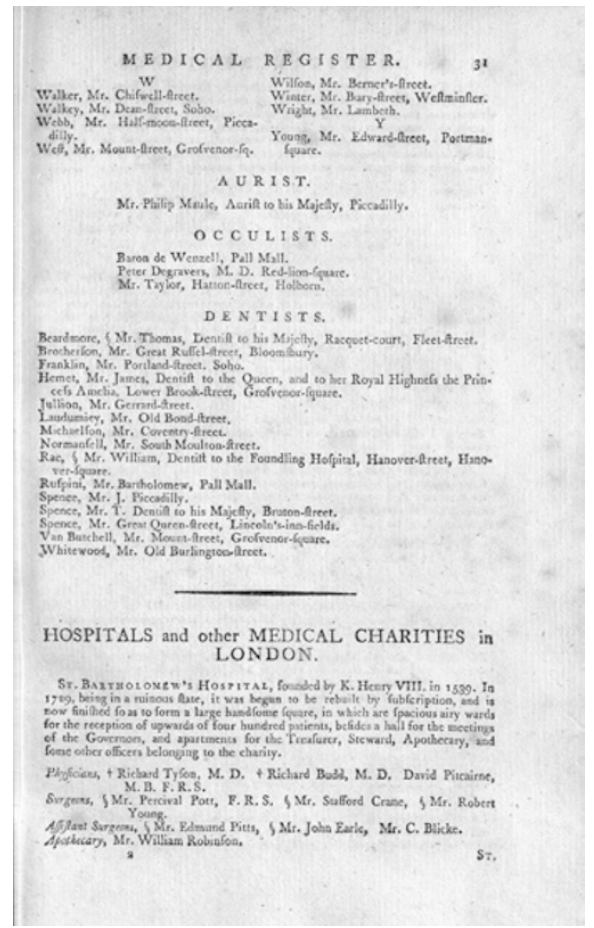

Fig. 1 The Medical Register for the year 1783. The British Library Board, pp 2487, eb page 31

Spence, Van Butchell and Whitewood. In Oxford there were Curtis Jun., and Rose (dentists to the Radcliffe Infirmary), and in Liverpool, R. Wooffendale (dentist to the Liverpool Dispensary).

\section{The importance of this development}

With this formal listing, 'dentist' replaced the old titles of 'operator for the teeth', (six of whom just 20 years earlier had been listed in Mortimer's Directory) ${ }^{4}$ and 'Toothdrawer'. 
As for acceptance by the public at large, (the subject of the second paper in this series), evidence shows that from the first recorded public use of the name dentist to describe dental operators in England, possibly by Paul Jullion in about 1752 (Fig. 2) ${ }^{5}$ or certainly by Joseph Grimaldi in $1759,{ }^{6}$ to the publication of a tract aimed not at the profession, but specifically at the public and entitled Every lady and gentleman their own dentist in $1791^{7}$ took just 40 years. The title had reached America by at least $1766^{8,9}$

\section{THE PREVIOUS UNSATISFACTORY SITUATION}

Previous papers in this journal have described the position of dentistry in England before the separation of the surgeons from the Barber Surgeons Company of London, preparing the way for this series that proposes the true commencement of the modern profession in the adoption of the name 'dentist' to describe practitioners of the art. ${ }^{10-13}$

To recap briefly, Lilian Lindsay established that in England the speciality of oral and dental care had been developed by "operators for the teeth' ${ }^{14}$ such as Allen, ${ }^{15}$ with Ann Hargreaves identifying and naming some 70 of these practitioners. ${ }^{16}$ What might very loosely be termed 'general dental practice', in the form of extractions and some measure of scaling had been offered by barbertoothdrawers. ${ }^{17}$ And at perhaps the lowest end of the scale, but still socially valuable, were itinerant or market tooth-drawers. ${ }^{18}$ Hargreaves is able to name almost the same number of these irregulars, but many more of these barber-toothdrawers and itinerants will be unknown.

There was no coherence in the titles, and certainly none fell within the third criterion for a title under which group political action could be taken. In the earlier part of the eighteenth century even the lowly 'Toothdrawer', as a professional title, was not solely associated in the public mind with barbers, as can be seen formalised when in 1738 Samuel Rutter (1696-1761), the specialist operator for the teeth, was entered in the Quarterage Book of the Company of Barber Surgeons as 'Toothdrawer. ${ }^{19} \mathrm{He}$ became Master of the Company in $1747^{20}$ (Fig. 3) immediately following the split when the surgeons won their independence. All these titles, (and the brief emergence of 'kindheart' - possibly from 'tandartz') were either too limited to describe dentistry, or in the case of operator for the teeth, too clumsy.

\section{INSULTS VEILED AND UNVEILED}

A further strong incentive to accept 'dentist' as the new title arose from the opportunity for insult, to which the old confusion of titles lent itself. A good example lies in a little piece of gossip recorded by Horace Walpole (Horatio Walpole, fourth Earl of Orford 1717-1797) in 1753, and identified by Hargreaves in her history. ${ }^{16}$ Walpole first correctly calls the Frenchman 'Lodomie' 'operator' - and then records Laudimier's florid response to the snub offered by Lady Petersham when she calls him Arracheur de dents, and Walpole repeats the slight in English, toothdrawer. (In France Laudumier [sic, there is no consistency in the spelling of his name] had his 'Approbation' as Chirurgeon dentiste to the King of Spain).

A somewhat satirical piece in the Edinburgh review of 1759, (which the compilers of the New English dictionary on historical principles, now the Oxford English dictionary, ${ }^{21}$ considered to contain the first use of the word dentist), cannot be regarded as complimentary to Rutter. 'Dentist figures it now in our newspapers, and may do well enough for a French puffer; but we fancy Rutter is content with being called a Touth drawer [sic]. ${ }^{22}$

\section{CANDIDATES FOR THE 'FRENCH PUFFER'}

A suitable candidate for a 'French puffer' who called himself a dentist was Paul Jullion (d.1766) - one of the Huguenots who had reinvigorated the speciality. The handbill for Jullion (Fig. 2) is filed in the Purland collection under the date 1752 , but this is unreliable since two newspaper cuttings in the same collection, and reliably dated for that year, refer to Jullion as 'operator for the teeth at the Two Heads, Coventry Street. ${ }^{23}$ It is, however, reasonable to accept that the handbill dates from between 1752 and the Edinburgh Review piece of 1759, particularly as the London Magazine of 1760 (see below under Professor Webb) cites him as a wellknown dentist. His Will, dated 1766, refers to him as 'dentist' rather than surgeon-dentist. An Italian contender was 'Signior' Grimaldi, who was called 'Dentist and operator for the teeth and gums' in Aris's Birmingham Gazette for 18 June of the same year, 1759, 3 months earlier than the Chronicle's mention of Rutter. A facsimile advertisement is reproduced by Hillam. ${ }^{24}$

\section{STEADY PROGRESS}

In April 1760 'the celebrated Professor Webb' of Oxford was called a 'distinguished dentist and dentologist' ${ }^{25}$ in a newspaper item that reinforces Paul Jullion's claim to priority, as it refers to him and to the desire seen in his hand-bill (Fig. 2), to 'rectify deficient heads'. Dentologist does not appear to have achieved any wide currency, but tooth-drawer and

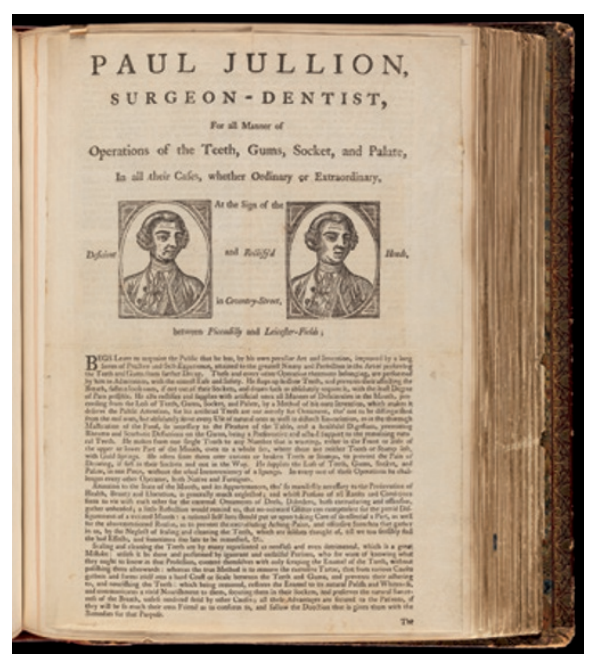

Fig. 2 The '1752' Jullion handbill. Purland Collection at the Wellcome Library. ${ }^{\circ}$ Courtesy of the Wellcome Collection

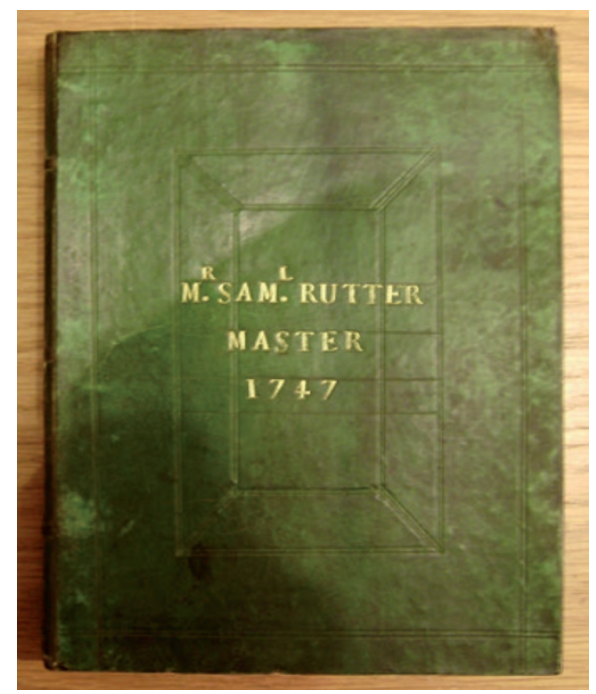

Fig. 3 The 1747 Quarterage book of the Company of Barber Surgeons of London. Samuel Rutter Master. ${ }^{\circ}$ By kind permission, the Honourable Company of Barbers of London

operator for the teeth coexisted with dentist for a few more years before dentist prevailed.

Between 1767 and 1787 the Liverpool practitioner Birch Hesketh, in his notices to the public, flipped between the two - operator for the teeth in 1767, 1769, 1772, and 1781, and dentist in 1774, 1777 and finally 1787. The spread of use of dentist in the provinces can be seen in Christine Hillam's definitive survey of trade journals, from which these Hesketh details have been isolated. ${ }^{24}$

The Town and Country Magazine of London managed to get all three terms, dentist, drawing of teeth, and operator into one paragraph as late as 1777 when describing the successes of an unnamed practitioner (evidence points to Jacob [James] Hemet); 'He was designed for a mercantile life, but not being very fond of plodding at the counting-house desk and having a lucky name for drawing of teeth, 
upon the demise of some of his relations who bore it and had gained reputation as dentists, he turned operator, as it were, in spite of his teeth. He dropt the pen and took up the pelican, which soon screwed him into chariot. ${ }^{26}$

Other terms appeared briefly, 'dentress' for a lady dentist ${ }^{27}$ and 'dentis', which is found in two records, one in America and one in the Barbers Quarterage book -which may both be accounted for as a phonetic rendering still to be heard today ('I'm going to the dentis').

\section{FOUR GENERATIONS OF DENTAL PROFESSIONALS: TOOTHDRAWER TO DENTIST}

The home team from Racquet Court in Fleet Street provides the neatest illustration of the rapid change in professional title, courtesy of four generations of practitioner at the head of the profession in the mideighteenth century. It may be doubted that Samuel Rutter ever practised under the title toothdrawer, but nevertheless, while at the very top, Master of the Honourable Company of Barbers, and famous, that is what he could properly be called, for as noted, that is how he had been entered in the Quarterage book when it was the united company.

In 1745 the Surgeons had won their freedom, ${ }^{28}$ and it is clear from the Quarterage book of the residual Honourable Company of Barbers that Rutter's younger partner William Green (c.1718-1764) was not prepared to continue to be associated with a title debased by common usage and open to such slights as seen earlier. He was admitted to the Company not as a barber but as a surgeon on the 4 September $1739,{ }^{29}$ and he continued into the Livery until 1742-3 under that title. ${ }^{30}$ For $1743-4$ there is a significant change and he is entered as 'Willm. Green. S. [for Surgeon] a tooth-drawer'. ${ }^{28}$ At the break he had to make a difficult decision, since he could have left with the surgeons but chose not to. By 1749/50, he is entered in the Company's Quarterage books as 'Green $\mathrm{W}^{\mathrm{m}}$ Operator for $\mathrm{y}^{\mathrm{e}}$ teeth ffleet St. ${ }^{31}$ He was appointed to the Royal Household in 1755 , and in 1764, the year in which his death is recorded by a ' $\mathrm{D}$ ' in the Quarterage Book, he is still listed as 'operator for the teeth.' ${ }^{32}$

In the third generation at Racquet Court, Green's apprentice and successor, the equally if not more famous Thomas Berdmore (1740-1785) although appointed under the old title operator for the teeth to George III from 1766, was to the public either surgeondentist or dentist, and features in the Medical Register of 1783 twice, once on the list of dentists and once as a Member of the Corporation of Surgeons, not the Barbers.
Robert Wooffendale (1742-1828) who annoyed Berdmore by turning 6 months of assistance into a claim of pupillage, ${ }^{33}$ in turn took the title surgeon dentist to America in $1766 .^{8,9}$ As already seen, having returned to England, he is entered as dentist to the Liverpool Infirmary in the 1783 Register.

\section{THE ACCEPTABILITY OF THE WORD DENTIST TO THE ENGLISH}

In France the dentiste had emerged as the specialist title, with Pierre Fauchard (c.1678-1761) in $1728^{34}$ playing a central role (although his work was not translated into English until the twentieth century) $)^{35}$ and the anglicised version proved ideal for adoption by both the specialists and the generalists when seeking a title after 1745 . The evidence is clear that after separation the Barbers Company held little appeal for those specialising in dentistry, and few of those doing so were qualified to move to the new Corporation of Surgeons of London (the Royal College title was not granted until 1800, and 'of England' in 1843).

Anglicising dentiste, to 'dentist' worked particularly well, having the great advantage that in English it was divorced from the demotic 'tooth'. Unlike the French, where dent a tooth, is incorporated in dentiste, and Chirurgeon dentiste in English there was no linguistic hangover from tooth-drawer or operator for the teeth. Pronounced in the English way 'dentist' related to the Latin dens/dentis, giving an air of education. Also at a time when France was not always particularly popular, 'dentist' did not suffer by association with the continent. Perhaps most usefully, the word was conveniently euphonious and alliterative with doctor.

\section{DR JOHNSON'S DICTIONARY AND THE FRENCH ENCYCLOPÉDIE}

The word dentist is omitted from any edition of Dr Johnson's dictionary during his lifetime, (1709-1784) or in the rest of the century, and while it might offend the sensibilities of the modern dentist to have his or her profession overlooked, while toothdrawer is there (but not operator for the teeth, or kindheart), is not surprising. The first occurrence of the word in England may, as said above, have been in 1752, or with certainty in 1759. Johnson's first edition was published in $1755,{ }^{36}$ work having been started in 1746 , and it is safe to assume that typesetting and collecting the words under the letter ' $\mathrm{D}$ ' predated that by a year, or perhaps more. Even thereafter, as Hillam pointed out, the number of dentists was fairly low, and further editions (five by 1786) did not see any introduction of the new word.
Perhaps more surprising is the fact noted by King $^{-37}$ that the Encyclopédie, first published in France in 1751, 23 years after Fauchard's seminal work La chirurgeon dentiste in 1728 , did not include the separate word dentiste. It first appeared as a professional title in 1776 in the Supplément. This can be explained if the French of Fauchard is translated as dental surgeon rather than surgeon dentist (although in England the latter usage was as familiar as dentist alone and was convenient for those few who were actually surgeons). Exactly by whom, or when, it was decided to drop the Chirurgeon (ien), and use dentiste as a noun rather than an adjective will probably never be known, but it was certainly in place in Paris by $1760 .{ }^{38}$

Johnson's dictionary does, however, show how easily the new word fitted into the Latinised words already in use at the time, so 'dental' is listed as an adjective from the Latin dentalis, belonging or relating to the teeth, also denticulated, from denticulatus, being set with small teeth, and dentifrice from the Latin dens and frico, a powder made to scour the teeth. Interestingly dentition (from dentitio) is defined as the act and time of breeding of children's teeth. Under 'tooth' as a noun is found the plural of dens, in dentes incisivi, or fore teeth, and: 'about the one-and-twentieth year the two last of the molares spring up, and they are called dentes sapientice.' Under 'tooth' as a verb is indent, to furnish with teeth.

\section{NEW MEN AND WOMEN IN A NEW PROFESSION}

In the later essays in this series, and in Hargreaves and Hillam's works, the briefest of glances at the names and countries of origin of the dentists recorded will show how many of the modernising 'dentists' were incomers, able to follow their calling under the new title, which they could not or would not have done as barbers or surgeons. Scottish, (Rae, the Spences) French (both the earlier Huguenots [Hemet, Jullion]), and others (Mme Rauxcourt, Laudimier, the Talmas, and later, like de Chemant, at the time of the revolution), Italian, (Grimaldi and Ruspini) Flemish, (van Butchell) German (Marks), Samuel Crawcour (1748-1816) was a Jew from Kracow and 'American' (Wooffendale, Whitewood), all played their role. In a profession that has appealed to the independent minded, mechanically able, people orientated and adventurous, it is perhaps not surprising that this continues to characterise the calling today. ${ }^{39}$

\section{SUMMARY}

This paper addresses self-awareness in what was effectively a new profession which, taking the name dentist from the French and 
making it its own, began to be established in the second half of the eighteenth century following the 1745 parting of the surgeons from the Company of Barber Surgeons of London. In doing so the paper illustrates the first requirement of Hancocks' editorial; 'until we can agree that identity among ourselves we cannot expect others to either understand our relationship to one another or indeed to respect our collective voice when we choose to, or need to, use it.'

1. Hancocks S. What's in a name? Br Dent J 2005; 199: 65.

2. Geo II c, 15. Anno 1745 An Act for making the Surgeons of London and the Barbers of London two separate and distinct Corporations. Statutes at Large. 6. 599-607.

3. The Medical Register for the year 1783. London: Joseph Johnson, 1783. Online register available at https://archive.org/details/medicalregisterf1783lond (accessed August 2014).

4. Wright D W. London dentists in the 18th century: listing from the trades directories in the Guildhall Library. Lindsay Club Newsletter 1986; 12: 8-16.

5. Handbill printed for Paul Jullion, possibly in 1752. Purland Collection, 1752.

6. Aris's Birmingham Gazette. 18 June, 1759.

7. Spilsbury F B. Every lady and gentleman their own dentist, as far as the operations will allow. Etc. London: Printed for the author, 1791.

8. New York Journal or General Advertiser 27 November 1766.

9. Pennsylvania Chronicle and Universal Advertiser, 15 January 1767.

10. Bishop $\mathrm{M}$. The ethics of dental practice in London in the sixteenth century. 2. Sir Thomas More's
'Ordinances' for the Barber Surgeons, 1530. Br Dent J 2012; 213: 77-80.

11. Bishop M, Gelbier S. Ethics and utopia; public health theory and practice in the sixteenth century. An essay comparing the Henrician Medical Act of 1540 and More's 1530 Ordinances, with Thomas More's novel Utopia of 1516. Br Dent J 2003; 195: 251-255.

12. Bishop M, Gelbier S, Gibbons D. Ethics - the early division of oral health care responsibilities by Act of Parliament. Br Dent J 2002; 192: 51-53.

13. Bishop M, Gelbier S, Gibbons D. Ethics - dental registration in the seventeenth and early eighteenth century. Br Dent J 2001; 191: 395-400.

14. Lindsay L. A short history of dentistry. London: J. Bale, sons and Danielsson Ltd, 1933.

15. Bishop M. Ars scientia mores: science comes to English dentistry in the seventeenth century. 2. Charles Allen's Treatise of 1685/6. Br Dent J 2013; 214: 239-242.

16. Hargreaves A S. White as whales bone, dental services in early modern England. Leeds: Northern Universities Press, 1998

17. Bishop M. A picture of dentistry at Charing Cross in the 1730s given by Hogarth's painting and print of Night. Professional governance, identity and possible mercury intoxication as an occupational hazard for his barber tooth-drawer. Br Dent J 2007; 203: $265-269$.

18. Bishop M. The ethics of dental practice in London in the sixteenth century. 1. Henry Chettle's Kind-Harts dreame of 1592. An important lay view. Br Dent J 2012; 213: 27-30.

19. Barber-Surgeons Company quarterage book, Vol 6 . London: Barber-Surgeons Company, 1738.

20. Barber-Surgeons Company quarterage book, Vol 13. London: Barber-Surgeons Company, 1747.

21. Murray J A. A new English dictionary on historical principles; founded mainly on the materials collected by the Philological Society. Vol III. DEEE. Oxford: Clarendon Press, 1897.

22. The Edinburgh Chronicle for 1759. Sept 15-18.
23. Dental services offered by Paul Jullion, surgeon dentist. Letterpress with woodcuts, ca. 1752. Purland Collection at the Wellcome Library. Fol.72r

24. Facsimile reproduced in Hillam C. Brass plate and brazen impudence. Dental practice in the provinces 1755-1855. Liverpool: Liverpool University Press, 1991

25. The London Magazine or Gentleman's Monthly Intelligencer 1760; 29: 204.

26. Town and Country Magazine 1777; 9: 233

27. Hargreaves A. Personal communication 25.10.2013. Daily Advertiser, 18 Feb 1751.

28. Barber-Surgeons Company quarterage book, Vol 11. London: Barber-Surgeons Company, 1743/4.

29. Barber Surgeons freedom register, Vol 5. 1732-1757.

30. Barber-Surgeons Company quarterage book, Vol 10. London: Barber-Surgeons Company, 1742/3.

31. Barber Surgeons Company quarterage book, Vol 15. London: Barber-Surgeons Company, 1749/50.

32. Barber Surgeons Company quarterage book, Vol 28. London: Barber-Surgeons Company, 1964.

33. Hillam C. Robert Wooffendale, the making of a reputation. Bulletin of the History of Dentistry 1993 41: 7-13.

34. Fauchard P. Le chirurgeon dentiste ou traité des dents. Paris: Jean Mariette, 1728

35. Fauchard P. Le chirurgien dentiste ou traité des dents. Being a facsimile of the 1746 French edition together with the Lindsay English translation of 1946. Birmingham Alabama: The Classics of Dentistry Library, 1980.

36. Johnson S. A dictionary of the English language in which the words are deduced from their originals and illustrated in their different significations by examples from the best writers: to which are prefixed a history of the language, and an English grammar. London: W. Strahan, 1755

37. King R. The making of the dentiste, c.1650-1760. Aldershot: Ashgate, 1998.

38. Jeze. Etat ou tableau de la ville de Paris. Prault, 1760

39. Hancocks S. One in three of us. Br Dent J 2011; 211: 99 